\title{
Effect of acoustic pulses and EHF radiation on multipotent marrow stromal cells in tissue engineering constructs
}

\author{
R. K. Chailakhyan*, , V. I. Yusupov ${ }^{\dagger}$, Yu. F. Gorskaya*, \\ A. I. Kuralesova*, Yu. V. Gerasimov*, A. P. Sviridov*, \\ A. Kh. Tambiev ${ }^{\S}$, N. N. Vorobieva ${ }^{\ddagger}$ A. G. Grosheva*, \\ V. V. Shishkova*, I. L. Moskvina* and V. N. Bagratashvilit, \\ ${ }^{*} N$. F. Gamaleya Research Institute of Epidemiology and \\ Microbiology Ministry of Health of the Russian Federation, \\ 18 Gamaleyi, Moscow 123098, Russia \\ ${ }^{\dagger}$ V. I. Il'ichev Pacific Oceanological Institute, \\ Far-Eastern Division of Russian Academy of Sciences, \\ 43 Baltiiskaya, Vladivostok 690041, Russia \\ Institute on Laser and Information Technologies of \\ Russian Academy of Sciences, 2 Pionerskaya, \\ Troitsk, Moscow 142190, Russia

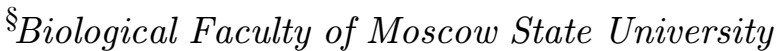 \\ 1-12 Leninskiye Gory, MSU, Moscow 119234, Russia \\ 9rubenchail@yandex.ru
}

Received 2 November 2015

Accepted 8 March 2016

Published 26 April 2016

\begin{abstract}
In this paper, we studied the effects of physical factors, such as, acoustic pulses of laser-induced hydrodynamics $(\mathrm{ALIH})$ and extremely-high frequencies (EHF) radiation, on the formation of heterotopic bone marrow organs. A suspension of precipitated bone marrow cells from CBA mice were exposed to ALIH pulses and EHF radiation separately and in their combination tissue engineering constructs, presenting gelatin sponges 2 by 2 by $2 \mathrm{~mm}$ in size containing $10^{7}$ nucleated bone marrow cells, were exposed to physical factors and were implanted under the renal capsules of syngeneic mice. The newly formed hematopoietic organs were examined in three and five months later after treatment. The five months old transplants were bigger in size than the three months old transplants. The number of hematopoietic cells in the rest of the groups increased during this period by a factor from 3 to 10, the increase being as high as 20-fold in the ALIH+EHF group. Maximal concentration of multipotent stromal cells (MSCs) was in the
\end{abstract}

\Corresponding author.

This is an Open Access article published by World Scientific Publishing Company. It is distributed under the terms of the Creative Commons Attribution 4.0 (CC-BY) License. Further distribution of this work is permitted, provided the original work is properly cited. 


\section{R. K. Chailakhyan et al.}

$\mathrm{EHF}+\mathrm{ALIH}$, and minimal concentration was in the ALIH+EHF. The accumulation rate of bone capsule weight was highest for the transplants of EHF+ALIH and ALIH-sponge groups during the first three months.

These data showed that the combined impact of the EHF+ALIH on MSCs is the most effective for the formation of bone marrow transplantation.

Keywords: Multipotent stromal cells; heterotopic transplantation; extremely high frequency radiation; laser-induced hydrodynamics; acoustic pulses.

\section{Introduction}

Nowadays, cell technologies constitute one of the most rapidly developing areas of biology and medicine. Regenerative medicine makes most widespread use of multipotent stromal cells (MSCs), ${ }^{1-3}$ that were discovered and described, as a new population of marrow stromal precursor cells in the studies. $^{4,5}$ Multipotent stromal cells are already being utilized in clinics to repair tissue defects in cases of extensive deep thermal skin injuries, ${ }^{6}$ to fill in facial soft tissue defects, ${ }^{7,8}$ to regenerate myocardium, ${ }^{9,10}$ to recover the integrity of bone tissues and hyaline cartilages of joints. ${ }^{11,12}$ The creation of various organs is the subject of current scientific research in many countries. ${ }^{13-15}$

However, the quantity of stem cells in a marrow punctate taken from a patient is insufficient for therapeutic purposes. The concentration of stromal precursor cells in the bone marrow is $(1-5) \times 10^{4}$; and in a suspension of hematopoietic cells they are strongly disunited by cells of different kinds. For this reason, to increase the quantity of the stromal cells prior to their transplantation to the recipient, they are cultivated in vitro. Effective methods were worked out to isolate these cells from the marrow and cultivate them in vitro, which provided for the increase in their numbers by more than $10^{5}$ times. ${ }^{16,17}$ Stromal progenitor cells, as well as their descendants have an enormous proliferation potential. ${ }^{18}$ By the 10th passage the numbers of fibroblasts in some strains increase up to $(1.2-7.2) \times 10^{9}$ cells. The cells undergoing up to 31-34 doublings in the course of their evolution.

Investigations $^{19}$ demonstrated that no abnormalities occurred in the chromosome set of MSCs preparations at first passages, while at higher ones (7th-10th) certain abnormalities, such as cells of altered caryotype, polyploidy, and so on, revealed themselves in individual cultures. In this regard, the development of methods for increasing their content in the bone marrow and activation of proliferative potencies in vitro, is one of the key goals of tissue engineering.

One of the approaches that have been developed in recent years is the exposure of tissues and cell cultures to various physical factors capable of stimulating these processes. Such factors, applied in the case of stem cells, include low-intensity laser and extremely-high frequency (EHF) electromagnetic radiations, acoustic waves and mechanical vibrations, and even ionizing radiation in small doses. ${ }^{20}$

To illustrate, exposure of mesenchymal stem cells grown in culture to electromagnetic radiation in the red and near-infrared regions of the spectrum in a dose on the order of $1 \mathrm{~J} / \mathrm{cm}^{2}$ increases their proliferation. ${ }^{21-23}$

A low-intensity mechanical stimulation of the cells at a frequency of $90 \mathrm{~Hz}^{24}$ or $200 \mathrm{~Hz}^{25}$ increases their proliferation and osteogenetic differentiation. Exposure to ultrasonic waves $1.5 \mathrm{MHz}$ in frequen$\mathrm{cy}^{26}$ and low-intensity electromagnetic millimeter waves $^{27}$ also proves effective.

In our previous in vivo studies, a short-term irradiation with a $\mathrm{CW}$ laser of moderate intensity $1.56 \mu \mathrm{m}$ in wavelength doubled the concentration of MSCs in the bone marrow. ${ }^{28}$ Exposure of MSCs in vitro to a low-intensity $\mathrm{He}-\mathrm{Ne}$ laser together with low-intensity EHF radiation resulted in a 1.5-2-fold increase of their proliferation activity. ${ }^{29}$

Another approach used by us is that cells are exposed to acoustic pulses of laser-induced hydrodynamic (ALIH) processes, which were found in water and water-saturated biotissues near fiber tip with laser radiation. ${ }^{30-32}$

Interest in conducting such investigations stems from the fact, that according to recent information, the mechanism, responsible behind the high curative effect of moderate-power $(1-10 \mathrm{~W})$ laser radiation in the treatment of various diseases, including such serious ones as osteochondrosis and osteomyelitis, ${ }^{32,33}$ is associated exactly with ALIH processes. We believe that the main role in the enhancement of 
the activity of cells is played by the wideband acoustic signal accompanying these processes. ${ }^{34} \mathrm{As}$ it was demonstrated in vitro studies ${ }^{35,37}$ the action of the ALIH processes and EHF radiation reliably resulted in a $40-80 \%$ increase of the proliferation activity of MSCs.

This work is aimed at investigating the effect of ALIH pulses and EHF radiation on the in vivo formation and final size of a bone marrow organ comprising a bony and a hematopoietic tissue.

\section{Materials and Methods}

Experiments were carried out on CBA mice contained in standard vivarium conditions in accordance with the requirements of the regulations governing the implementation of research on the safety and efficacy of pharmacological agents in the Russian Federation (Order of the Ministry of Health of Russian Federation "On approval of rules of good laboratory practice" No. 267 from 19.06.2003) and the international rules of legal and ethical use of animals. The study was performed under the clinical and animal study ethical committee permission of the N. F. Gamaleya Federal Research Centre of Epidemiology and Microbiology.

A suspension of precipitated bone marrow cells from CBA mice were exposed to ALIH pulses and EHF radiation separately and also in combination in different sequences $\mathrm{ALIH}+\mathrm{EHF}$, EHF+ALIH. Tissue engineering constructs (scaffolds in the form of gelatin sponges 2 by 2 by $2 \mathrm{~mm}$ in size containing $10^{7}$ nucleated bone marrow cells) were then prepared. To grow bone marrow organs, all the tissue-engineering constructs were implanted under the renal capsules of syngeneic mice. All the experimental mice were divided into the following six groups (of seven animals each) in accordance with the kind of the physical factor their transplanted cells were exposed to: (1) EHF, (2) EHF+ALIH, (3) ALIH, (4) ALIH+EHF, (5) ALIH in sponge, (6) control-unexposed. The cells in group 5 (ALIH-sponge) were first embedded in a sponge and then exposed to ALIH pulses. The transplants were examined within three and five months of treatment. Subject to investigation in the newly formed hematopoietic organs were the total number of hematopoietic cells, efficiency of colony formation of MSCs (ECF-MSCs), the number of MSCs, and the weight of the bone capsule of the transplant.
Physical factors used to treat bone marrow cells. (1) MSCs, either precipitated in a test tube or embedded in a sponge, were exposed to ALIH pulses in an original apparatus-ALIH simulator. ${ }^{35}$

Prior to experiment, the memory block of the simulator was loaded with an acoustic signal obtained when forming laser channels in the nucleus pulposus of intervertebral disc in vitro. ${ }^{32}$

As can be seen from Fig. 1, this wideband acoustic signal is a quasiperiodic sequence of short pulses $2 \mathrm{kPa}$ in pressure amplitude, which are known ${ }^{29-31,33}$ to be associated with the generation and cavitation collapse of steam-gas bubbles near the hot tip of the laser fiber. During experiment by means of a piezoceramic transducer the recorded signal initiates the acoustic pulses, similar to those shown in Fig. 1, in the water-filled chamber of the ALIH apparatus. The MSCs under test, either precipitated or embedded in a sponge, were placed, together with the culture solution, in a test tube that was then immersed in the operating cell of the ALIH apparatus and exposed to ALIH pulses for $50 \mathrm{~s}$.

(2) Exposure of precipitated MSCs to a lowintensity EHF radiation $7.1 \mathrm{~mm}$ in wavelength and $5 \mathrm{~mW} / \mathrm{cm}^{2}$ in power density was carried out with a EHF source (Akvastin IRE-Polyus, Russia). A test tube, containing the precipitated MSCs of interest, was placed at the output of the EHF emitter. The exposure time came to $30 \mathrm{~s}$, which corresponded to an exposure dose of $150 \mathrm{~mJ} / \mathrm{cm}^{2}$.

(3) The combined effect of ALIH pulses and EHF radiation on bone marrow cells was studied using

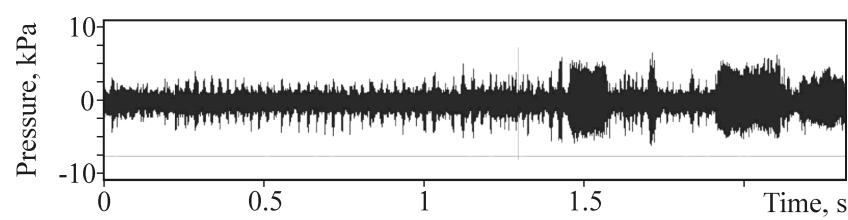

(a)

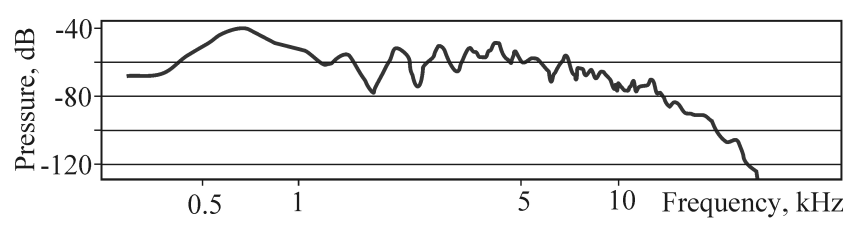

(b)

Fig. 1. Fragment of the ALIH simulator acoustic signal used to treat precipitated or sponge-embedded mesenchymal stromal cells: (a) ALIH signal and (b) signal spectrum. 


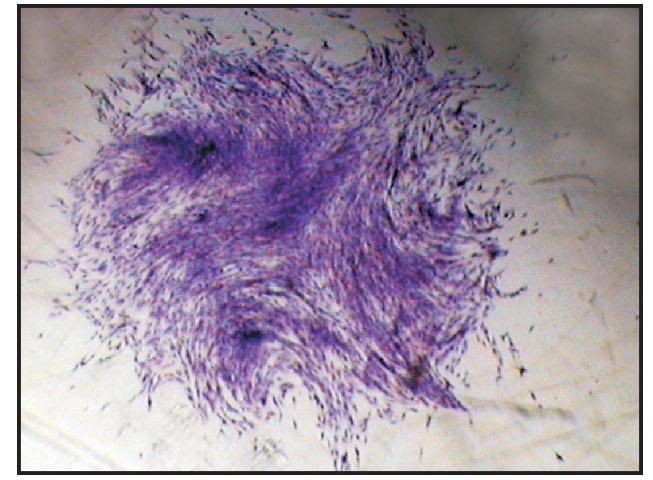

(a)

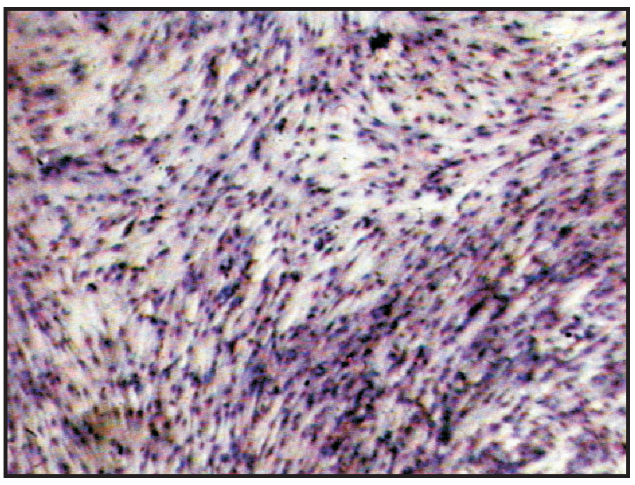

(b)

Fig. 2. Clone colony (a) formed by marrow stromal precursor cells in a monolayer culture and the structure of colony (b).

these factors in the following sequences and regimens: ALIH $50 \mathrm{~s} /$ pause $60 \mathrm{~s} / \mathrm{EHF} 30 \mathrm{~s}$; EHF $30 \mathrm{~s} /$ pause $60 \mathrm{~s} / \mathrm{ALIH} 50 \mathrm{~s}$.

MSCs precipitated in test tubes were treated using one of the following four exposure regimens: $\mathrm{ALIH}, \mathrm{EHF}, \mathrm{ALIH}+\mathrm{EHF}$, and EHF+ALIH. The cells embedded in sponges were exposed to ALIH pulses only. The controls were sponge transplants containing unexposed cells.

Preparation of Bone Marrow Suspension. The shin and thigh bones of ether-killed mice were excised. The epiphyses of the bones were cut off and the bone marrow was then washed out into a nutritional medium with a syringe. A homogeneous marrow cell suspension was prepared. The suspension obtained was filtered through a 4-ply kapron filter and the number of cells was then counted. The cells were centrifuged (10 min, $1000 \mathrm{rpm})$ at $4^{\circ} \mathrm{C}$.

Transplantation under the Renal Capsule. A longitudinal incision was made on the left side of the anterior abdominal wall of mice under Nembutal anesthesia $(40 \mathrm{mg} / \mathrm{kg})$, through which the left kidney was exteriorized. With the kidney held fast, a small pouch was formed with a pair of eye forceps under its capsule, into which a sponge containing $10^{7}$ marrow cells was transplanted.

Extraction of Hematopoietic Cells from Transplants and Their Explantation to Tissue Cultures. The formed hemopoietic organ was isolated from the renal capsule and placed in a hole with $1 \mathrm{ml}$ of medium. Hematopoietic tissue was separated from the bone capsule using of an ophthalmic scalpel; a suspension of bone marrow cells was prepared and is filtered through a 4-ply nylon filter; the number of isolated cells was counted. Cells were explanted in $25 \mathrm{~cm}^{2}$ culture flasks (NUNC) (on the basis of 1.0-2.0 h 105 cells per vial) with $5 \mathrm{ml}$ of complete medium consisting of $80 \%$ of $\alpha$-MEM (Sigma), $20 \%$ serum cow embryos (Ny clone) and antibiotics.

Cultivation was conducted at $37^{\circ} \mathrm{C}$ under $5 \%$ $\mathrm{CO}_{2}$. Discrete colonies clones, consisting of several thousand fibroblast, were formed in monolayer cultures of bone marrow cells at 12-14 days (Fig. 2). The clonal nature of the colonies permits to determine the number of MSCs in the test suspension. ${ }^{4}$ To calculate the number of colonies, cultures were washed twice with saline solution, fixed $70^{\circ}$ ethanol and stained with azure-eosin. The efficiency colony formation (ECF) of MSCs (number of grown colonies produced after explantation of $10^{5}$ bone marrow cells) was estimated by the number of grown colonies of stromal fibroblasts.

Determination of the Dry weight of the Bone Capsule. The bone capsules, left to stay overnight in $70^{\circ}$ alcohol, were removed and transferred for $30 \mathrm{~min}$ to an ether/alcohol (50/50) mixture and thereafter to pure ether for an hour. Within $5-10 \mathrm{~min}$ after the removal of the capsules from ether, their dry weight was determined.

Statistical Processing of the Results. The data of interest were presented in the form of averages for no less than three experiments, together with standard deviations, $M \pm m$. The results were compared using the Student $t$-test, the differences being considered statistically valid at $p \leq 0.05$.

\section{Results and Discussion}

This work is a continuation of research of separate or combined effect of various physical factors on MSCs. It was shown that the impact of the certain physical factor, in particular, on the precipitated 
cells of different origins gives a various results. Exposure to EHF radiation and acoustic pulses of ALIG on MSCs of rabbit did not lead to increasing proliferative activity of cells in vitro. The trend towards inhibition of proliferative activity was observed for the combined impact in sequence $\mathrm{EHF}+\mathrm{ALIG}$. However, a statistically significant $(p<0.05)$ increase in cell proliferation $(80 \%)$ relative to the control results were observed in all cases at the action of acoustic pulses on human MSCs. At the same time, the proliferative activity of the human and rabbit MSCs, which were adhered on plastic culture plates, increased in 2.5-3 times under EHF radiation. Studies such as the perosseous heating of bone marrow of a rat shin using the helium-neon laser radiation in vivo, as well as the impact of EHF radiation by means of a submersible antenna on the suspension of bone marrow cells in vitro, which led to similar results - a doubling of MSCs in the bone marrow, deserve attention. Previously, we have studied the effect of physical factors either on a change of the proliferative activity of MSCs in vitro, or on MSCs content in the bone marrow. In this study, the impact of physical impacts on MSCs that form the heterotopic hematopoietic organs under the kidney capsule was studied along five parameters.

Investigations conducted within three and five months after transplantation showed that in all cases hematopoietic organs successfully formed in place of the transplants (Fig. 3). As one can see from this figure, distinct under the renal capsule is a bone capsule; and beneath it and over the renal tissue there are hematopoietic cells.

During the period between three and five months after transplantation, the transplants grew much larger. This agrees with the data, ${ }^{36,38,39}$ obtained earlier, and is supported by the results of the

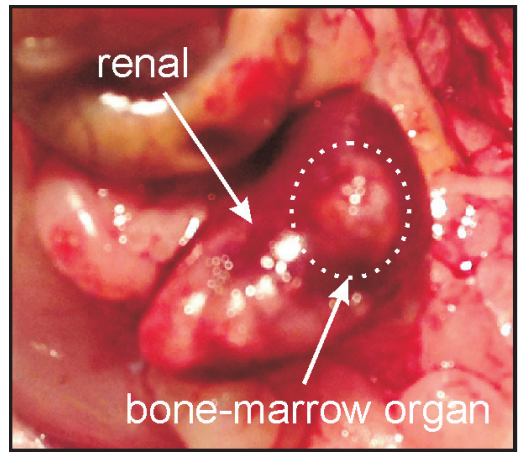

(a)

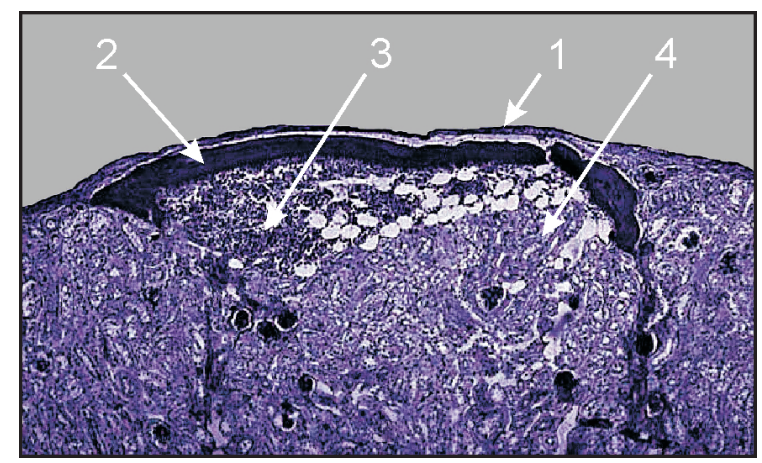

(b)

Fig. 3. Microphotograph of a bone marrow organ formed under a renal capsule: 1 is renal capsule; 2 is bone capsule; 3 is bone marrow; 4 is renal tissue.

hematopoietic cell counts (Tables 1 and 2). Within five months the number of these cells in the control group came to $(5.9 \pm 1.2) \times 10^{6}$; i.e., they multiplied by more than three times as compared with their quantity within three months of transplantation. The number of hematopoietic cells in the rest of the groups increased during this period by a factor from 3 to 10 , the increase being as high as 20-fold in

Table 1. Cell number, ECF-MSCs, weight of bone capsules, and phosphatase-positive colonies in three months transplants of bone marrow in mice $(M \pm m)$.

\begin{tabular}{lccccc}
\hline $\begin{array}{l}\text { Group type of } \\
\text { physical factors }\end{array}$ & $\begin{array}{c}\text { Number of nucleated } \\
\text { cells, } \times 10^{6}\end{array}$ & ECF*-MSCs, $\times 10^{5}$ & $\begin{array}{c}\text { Number } \\
\text { of MSCs }\end{array}$ & $\begin{array}{c}\text { Dry weight of } \\
\text { bone capsule, mg }\end{array}$ & $\begin{array}{c}\text { Phosphatase-positive } \\
\text { colonies, \% }\end{array}$ \\
\hline EHF & $0.4 \pm 0.1$ & $5.8 \pm 0.6$ & $24 \pm 6$ & $0.5 \pm 0.2$ & $33 \pm 6$ \\
EHF+ALIH & $1.6 \pm 0.5$ & $2.7 \pm 0.2$ & $43 \pm 14$ & $1.2 \pm 0.3$ & $27 \pm 4$ \\
ALIH & $0.9 \pm 0.3$ & $0.5 \pm 0.1$ & $4.0 \pm 1$ & $0.7 \pm 0.3$ & $21 \pm 1$ \\
ALIH+EHF & $0.13 \pm 0.0$ & $7.6 \pm 1.1$ & $10 \pm 2$ & $0.7 \pm 0.3$ & $27 \pm 2$ \\
ALIH-sponge & $1.5 \pm 0.5$ & $1.8 \pm 0.3$ & $26 \pm 9$ & $1.7 \pm 0.3$ & $23 \pm 3$ \\
Control & $1.8 \pm 0.7$ & $1.1 \pm 0.1$ & $20 \pm 8$ & $0.7 \pm 0.4$ & $20 \pm 3$ \\
\hline
\end{tabular}

*ECF is efficiency of colony formation. 


\section{R. K. Chailakhyan et al.}

Table 2. Cell number, ECF-MSCs, weight of bone capsules, and phosphatase-positive colonies in five months transplants of bone marrow in mice $(M \pm m)$.

\begin{tabular}{|c|c|c|c|c|c|}
\hline $\begin{array}{l}\text { Group type of } \\
\text { physical factors }\end{array}$ & $\begin{array}{c}\text { Number of nucleated } \\
\text { cells, } \times 10^{6}\end{array}$ & ECF ${ }^{*}$-MSCs, $\times 10^{5}$ & Number of MSCs & $\begin{array}{l}\text { Dry weight of } \\
\text { bone capsule, mg }\end{array}$ & $\begin{array}{c}\text { Phosphatase-positive } \\
\text { colonies, } \%\end{array}$ \\
\hline $\mathrm{EHF}$ & $4.0 \pm 1.3$ & $3.4 \pm 0.1$ & $134 \pm 44$ & $1.0 \pm 0.4$ & $39 \pm 4$ \\
\hline $\mathrm{EHF}+\mathrm{ALIH}$ & $7.5 \pm 2.3$ & $2.3 \pm 0.2$ & $170 \pm 53$ & $2.0 \pm 0.5$ & $31 \pm 2$ \\
\hline ALIH & $3.1 \pm 1.0$ & $1.5 \pm 0.1$ & $42 \pm 14$ & $1.0 \pm 0.2$ & $21 \pm 2$ \\
\hline $\mathrm{ALIH}+\mathrm{EHF}$ & $2.6 \pm 1.2$ & $0.8 \pm 0.1$ & $21 \pm 8$ & $1.0 \pm 0.4$ & $30 \pm 4$ \\
\hline ALIH-sponge & $4.9 \pm 0.8$ & $2.0 \pm 0.4$ & $100 \pm 23$ & $2.2 \pm 0.3$ & $25 \pm 3$ \\
\hline Control & $5.9 \pm 1.2$ & $1.4 \pm 0.3$ & $80 \pm 16$ & $2.2 \pm 0.3$ & $22 \pm 2$ \\
\hline
\end{tabular}

${ }^{*} \mathrm{ECF}$ is efficiency of colony formation.

the EHF+ALIH group. Within five months after transplantation, the number of hematopoietic cells in all groups, except for ALIH+EHF group, did not differ reliably from the controls; in the ALIH+EHF group it was much lower: a mere $44 \%$ of the control value.

One can see from Tables 1 and 2 that the maximum MSCs concentration was observed in the transplants of the EHF+ALIH group, both within three and five months after treatment, and was more than two times as high as the corresponding control values. It is interesting to note that treatment in the opposite order, namely, $\mathrm{ALIH}+\mathrm{EHF}$ group, reliably led to a gradual decrease of the MSCs concentration in the transplants to $50 \%$ within three months and to $26 \%$ of the corresponding control values within five months of treatment. During the period between three and five months after transplantation the increase in the MSCs concentration in all the other groups is caused mainly from the increase in the number of hematopoietic cells in a transplants. The extent of this increase in the EHF+ALIH and ALIH-sponge groups (in 3.9-fold) did not differ significantly from the control group (4-fold). The increase in the EHF group was higher (5.6-fold), while in the $\mathrm{ALIH}+\mathrm{EHF}$ group it was reliably lowered (2.1-fold during three months).

The minimum MSCs concentration per transplant was observed after three months in the ALIH group, amounting to $20 \%$ of the control values. However, it increased to $50 \%$ of control values after five months. In the ALIH-sponge group the MSCs concentration was substantially higher (by six times) than in the ALIH group and exceeded the control level by a factor of 1.3 , but it was lower by a factor of 1.7 than in the EHF+ALIH group. After five months exceeding the MSCs concentration in the ALIH-sponge group over the ALIH group was only by a factor of 2.5 times.

At EHF treatment, the MSCs concentration was higher by 1.2 times than in the control group after three months and 1.7 times after five months.

Note that the results of these in vivo studies into the proliferation of MSCs confirmed the results obtained by us in the preceding in vitro investigations, ${ }^{35,37}$ where the enhancement of the proliferation activity of MSCs reached $40-80 \%$ in the cases of their exposure to ALIH pulses and to combined $\mathrm{EHF}+\mathrm{ALIH}$ effects.

Thus, the relationships between the MSCs concentrations in the corresponding three and five months old transplants were similar; i.e., the differences in quality between the transplants due to their being exposed to different physical factors were conserved and sustained over the entire lifetime of the transplants. Bearing in mind the fact that the organization of the transplants is realized by the cells from the MSCs population that are responsible for transplantability, ${ }^{26}$ one can conclude that the physical factors used in this work were aimed, among others, at this category of cells.

As for the efficiency of colony formation, during the period between three and five months after transplantation the number of colonies in each group varied comparatively little: changes almost did not happen in the EHF+ALIH, ALIH in sponge groups, and control; for EHF group it decreased by a factor of 1.7 after five months. The exception is again the ALIH+EHF group, where the number of colonies dropped by a factor of 9.5 .

The plots in Fig. 4 present the numbers of MSCs and dry weights of bone capsules, normalized to the corresponding average control values, within three and five months after exposure to the physical 


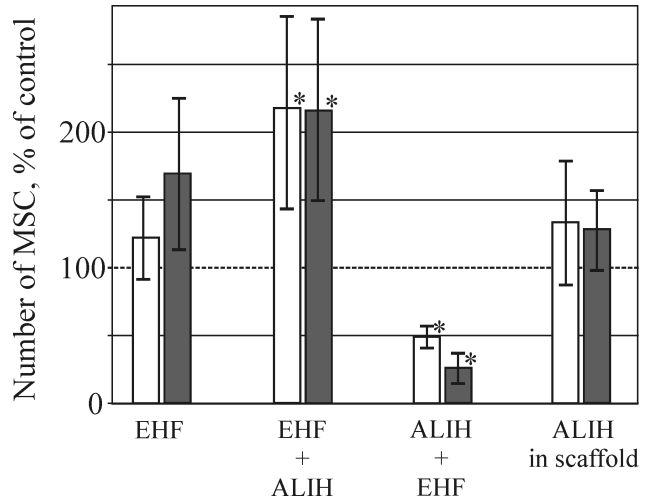

(a)

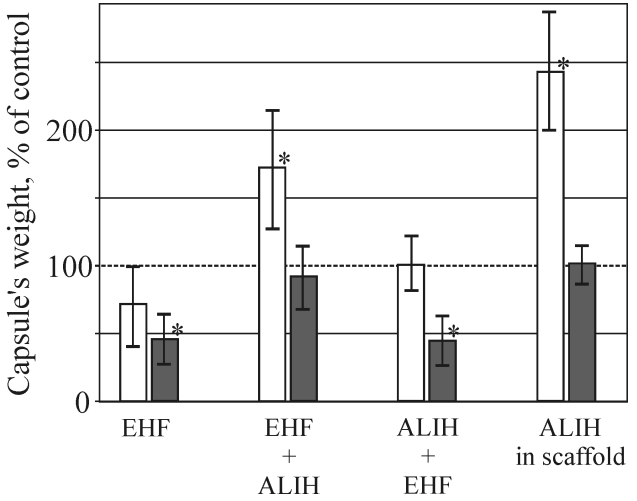

(b)

Fig. 4. (a) Number of MSCs per transplant and (b) dry weight of bone capsule within three months (open columns) and five months (full columns) after exposure to the physical factors. The asterisks indicate the results reliably differing from the controls $(p<0.05, n \geq 3)$.

factors. With such representation, the control values in both plots correspond to unity.

As can be seen from Fig. 4(b) and Tables 1 and 2, the dry weight of the three months old bone capsules in the EHF+ALIH and ALIH-sponge was greater by a factor of 1.7 and 2.4 , respectively, than in the control groups. The bone capsule weights in the EHF groups and ALIH+EHF groups within three months after treatment did not differ from the control groups.

The corresponding results for the five months old bone capsules in the EHF+ALIH and ALIH-sponge groups did not differ reliably from the controls, whereas those for the bone capsule weights in the $\mathrm{EHF}$ and $\mathrm{ALIH}+\mathrm{EHF}$ groups showed them to be more than half as high as in the controls.

The ability to osteogenesis is one of the fundamental properties of MSCs, which identified areas of initial use of MSCs for orthopedics and traumatology. Due to this, the determination of the number of colonies, positive for alkaline phosphatase, which is the main indicator of osteogenesis cells, is very relevant. In the three months old transplants, the number of phosphatase-positive colonies in the $\mathrm{EHF}+\mathrm{ALIH}$ and ALIH+EHF groups exceeded over the "control" groups by a factor of 1.3-1.4. The most high exceeding (by 1.6 times) of the number of phosphatase-positive colonies was in the EHF group. In the five months old transplants such exceeding was kept in the groups mentioned above.

It could be assumed that in the newly formed blood-forming organ the number of nucleated cells can play a role of a determining parameter of physical factors influence. However, our studies have shown that there is no correlation between such parameters as the number of nucleated cells, the bone capsule mass, number of MSCs and other. This indicates that the formation of the transplants has its own characteristics after each physical effects in different experimental groups. A correlation was observed only in separate groups, even for such parameters, close in their effects, as mass of the bone capsule and the percentage of phosphatasepositive colonies.

Our investigations showed that in transplants with a comparatively small number of hematopoietic cells the quantity of MSCs was, more often than not, lowered as well, there being no correlation between the weight of the bone capsule on the one hand and the numbers of hematopoietic cells and MSCs on the other hand. Also, no correlation was observed to occur between the number of hematopoietic cells in the transplants and the efficiency of colony formation of MSCs. Thus, the abovementioned groups of transplants are observed to differ by the relations between the number of hematopoietic cells, the efficiency of colony formation of MSCs, their quantity, and bone capsule weight. From this, it apparently follows that the process of formation of the transplants following their exposure to each individual physical factor featured specifics of its own.

On the whole, it follows from the results obtained that the combined effect of EHF radiation and ALIH pulses proved most favorable for the formation of bone marrow organs, providing for the maximum MSCs concentration in the transplants (2.2 times as high as in the control) and a bone 
capsule weight comparable with the control value. What is very important is that the bone capsule weight accumulation rate in the transplant of EHF+ALIH and ALIH-sponge groups during the first three months after transplantation exceeded that in the control groups by a factor of 1.7 and 2.4 , respectively. This suggests that these physical factors can be used to accelerate rehabilitation processes.

This work was supported by the Russian Foundation grant 14-25-00055 (in the part of LIH and EHF treatment methods) and by Russian Foundation for Basic Research, grants 13-02-00438 and 1304-12032 (in the part of the cell and transplant experiments).

\section{References}

1. M. F. Pittenger, A. M. Mackay, S. C. Beck, R. K. Jaiswal, R. Douglas, J. D. Mosca, M. A Moorman, D. W. Simonetti, S. Craig, D. R. Marshak, "Multilineage potential of adult human mesenchymal stem cells," Science 284, 143-147 (1999).

2. A. I. Caplan, "Review: Mesenchymal stem cells: Cell-based reconstructive therapy in orthopedics," Tissue Eng. 11, 1198-1211 (2005).

3. A. I. Caplan, "Adult mesenchymal stem cells for tissue engineering versus regenerative medicine." J. Cell. Physiol. 213, 341-347 (2007).

4. R. K. Chailakhyan, K. S. Lalykina, "Spontaneous and induced differentiation of osseous tissue in a population of fibroblast-like cells obtained from long-term monolayer cultures of bone marrow and spleen," Doklady Akademii nauk SSSR 187, 473-479 (1969) (in Russian).

5. A. J. Friedenstein, R. K. Chailakhyan, K. S. Lalykina, "The development of fibroblasts colonies in monolyer cultures of guines pig bone marrow and spleen cells," Cell Tissue Kin. 3, 393-403 (1970).

6. J. J. Lataillade, C. Doucet, E. Bey, H. Carsin, C. Huet, I. Clairand, J. F. Bottollier-Depois, A. Chapel, I. Ernou, M. Gourven, L. Boutin, A. Hayden, C. Carcamo, E. Buglova, M. Joussemet, T. de Revel, P. Gourmelon, "New approach to radiation burn treatment by dosimetry-guided surgery combined with autologous mesenchymal stem cell therapy," Regen. Med. 2, 785-794 (2007).

7. M. Zhu, Z. Zhou, Y. Chen, R. Schreiber, J. T. Ransom, J. K. Fraser, M. H. Hedrick, K. Pinkernell, H.-C. Kuo, "Supplementation of fat grafts with adipose-derived regenerative cells improves longterm graft retention," Ann. Plast. Surg. 64, 222-228 (2010).
8. K. Yoshimura, H. Suga, H. Eto, "Adipose-derived stem/ progenitor cells: Roles in adipose tissue remodeling and potential use for soft tissue augmentation," Regen. Med. 4, 265-273 (2009).

9. S. L. Chen, W. W. Fang, F. Ye, Y. H. Liu, J. Qian, S. J. Shan, J. J. Zhang, R. Z. Chunhua, L. M. Liao, S. Lin, J. P. Sun, "Effect on left ventricular function of intracoronary transplantation of autologous bone marrow mesenchymal stem cell in patients with acute myocardial infarction," Am. J. Cardiol. 94, 92-95 (2004).

10. G. V. Silva, S. Litovsky, J. A. R. Assad, A. L. S. Sousa, B. J. Martin, D. Vela, S. C. Coulter, J. Lin, J. Ober, W. K. Vaughn, R. V. C. Branco, E. M. Oliveira, R. He, Y.-J. Geng, J. T. Willerson, E. C. Perin, "Mesenchymal stem cells differentiate into an endothelial phenotype, enhance vascular density, and improve heart function in a canine chronic ischemia model," Circulation 111, 150-156 (2005).

11. N. Petite, V. Viateau, W. Bensaid, A. Meunier, C. de Pollak, M. Bourguignon, K. Oudina, L. Sedel, G. Guillemin, "Tissue -engineered bone regeneration," Nat. Biotechnol. 18, 959-963 (2000).

12. R. K. Gupta, A. K. Das, A. Chullikana, A. S. Majundar, "Mesenchymal stem cells for cartilage repair in osteoarthritis," Stem Cell Res. Ther. 3, 2534 (2012).

13. T. Cui, R. Terlecki, A. Atala, "Tissue engineering in urethral reconstruction," Arch. Esp Urol. 67, 29-34 (2014).

14. A. Gonfiotti, M. O. Jaus, D. Barale, S. Baiguera, C. Comin, F. Lavorini, G. Fontana, O. Sibila, G. Rombolà, P. Jungebluth, P. Macchiarini, "5-year Follow-up of the first tissue engineered airway transplantation," Lancet 383, 238-244 (2014).

15. M. E. Scarritt, N. C. Pashos, B. A. Bunnell, "A Review of Cellularization Strategies for Tissue Engineering of Whole Organs," Front. Bioeng. Biotechnol. 3, 43 (2015).

16. A. J. Friedenstein, R. K. Chailakhyan, Yu. V. Gerasimov, "Bone marrow osteogenig stem cells: In vitro cultivation and transplantation in diffusion chambers," Cell Tissue Kin. 20, 263-272 (1987).

17. R. K. Chailakhyan, Yu. V. Gerasimov, M. R. Chailakhyan, A. A. Galoyan, "Proline-rich hypothalamic polypeptide has opposite effects on the proliferation of human mormal bone marrow stromal cells and human giant-cell tumour stromal cell," Neurochem. Res. 35, 934-939 (2010).

18. R. K. Chailakhyan, Yu. V. Gerasimov, A. I. Kuralesova, N. V. Latsinik, E. N. Genkina, M. R. Chă̌lakhian, "Proliferative and Differetiation Potential of Individual Clones Derived from Bone Marrow Stromal Precursor Cells," Izvestiya Academii Nauk. 6, 682-692 (2001), (in Russian). 
19. D. Rubio, J. Garsia-Castro, M. C. Martin, R. de la Fuente, J. C. Cigudosa, A. C. Lloyd, A. Bernard, "Spontaneous human adult stem cell transformation," Cancer Res. 65, 3035-3039 (2005).

20. X. Liang, Y. H. So, J. Cui, K. Ma, X. Xu, Y. Zhao, L. Cai, W. Li, "The low-dose ionizing radiation stimulates cell proliferation via activation of the MAPK/ERK pathway in rat cultured mesenchymal stem cells," J. Rad. Res. 52, 380-386 (2011).

21. H. Tuby, L. Maltz, U. Oron, "Low-level laser irradiation (LLLI) promotes proliferation of mesenchymal and cardiac stem cells in culture," Lasers Surg. Med. 39, 373-378 (2007).

22. J. F. Hou, H. Zhang, X. Yuan, J. Li, Y. J. Wei, S. S. $\mathrm{Hu}$, "In vitro effects of low-level laser irradiation for bone marrow mesenchymal stem cells: Proliferation, growth factors secretion and myogenic differentiation," Lasers Surg. Med. 40, 726-733 (2008).

23. F. D. P. Eduardo, D. F. Bueno, P. M. de Freitas, M. M. Marques, M. R. Passos-Bueno, C. D. P. Eduardo, M. Zatz, "Stem cell proliferation under low intensity laser irradiation: A preliminary study," Lasers Surg. Med. 40, 433-438 (2008).

24. Y. K. Luu, E. Capilla, C. J. Rosen, V. Gilsanz, J. E. Pessin, S. Judex, C. T. Rubin, "Mechanical Stimulation of Mesenchymal Stem Cell Proliferation and Differentiation Promotes Osteogenesis While Preventing Dietary-Induced Obesity," J. Bone Miner. Res. 24, 50-61 (2009).

25. Z. Tong, R. L. Duncan, X. Jia, "Modulating the behaviors of mesenchymal stem cells via the combination of high-frequency vibratory stimulations and fibrous scaffolds," Tissue Eng. A 19, 1862-1878 (2013).

26. S. Noriega, T. Mamedov, J. A. Turner, A. Subramanian, "Intermittent applications of continuous ultrasound on the viability, proliferation, morphology, and matrix production of chondrocytes in $3 \mathrm{D}$ matrices," Tissue Eng. 13, 611-618 (2007).

27. O. V. Betskii, N. N. Lebedeva, Low-intensity millimeter waves in biology and medicine, Bioelectromagnetic Medicine, P. J. Rosch, M. S. Markov, Eds., pp. 741-759, Marcel Dekker, New York (2004).

28. R. K. Chailakhyan, Yu. V. Gerasimov, A. P. Sviridov, A. V. Kondyrin, A. H. Tambiev V. N. Bagratashvili, "Effect of IR laser radiation on the multipotent mesechymal stromal stem cells of rat marrow in vivo," Russ. Immunol. 3, 318-322 (2009).

29. R. K. Chailakhyan, V. I. Yusupov, J. V. Gerasimov, P. A. Sobolev, A. H. Tambiev, N. N. Vorobieva, A. P. Sviridov, V. N. Bagratashvili, Proliferation of normal and suppressed bone marrow stromal stem cells under physical actions, The twentieth Ann. Int. Laser Physics Workshop (LPHYS'11), Sarajevo, p. 169 (2011).
30. V. I. Yusupov, V. M. Chudnovskii, V. N. Bagratashvili, "Laser-Induced Hydrodynamics in WaterSaturated Biotissues. 1. Generation of Bubbles in Liquid," Laser Phys. 20, 1641-1647 (2010).

31. V. I. Yusupov, V. M. Chudnovskii, V. N. Bagratashvili, "Laser-induced hydrodynamics in watersaturated biotissues: 2. Effect on delivery fiber," Laser Phys. 21, 1230-1234 (2011).

32. V. I. Yusupov, V. M. Chudnovskii, V. N. Bagratashvili, "Laser-Induced Hydrodynamics In Water And Biotissues Nearby Optical Fiber Tip", Hydrodynamics - Advanced Topics, H. E. Schulz, A. L. A. Simoes, R. J. Lobosco, Eds., Chap. 5, pp. 95-118, Intech, Croatia - European Union (2011).

33. V. A. Privalov, I. V. Krochek, A. V. Lappa, "Diode laser osteoperforation and its application to osteomyelitis treatment," Proc. SPIE 4433, 180-185 (2001).

34. V. I. Yusupov, V. V. Bulanov, V. M. Chudnovskii, V. N. Bagratashvili, "Laser-induced hydrodynamics in water-saturated tissue: III. Optoacoustic effects," Laser Phys. 24, 015601 (2014).

35. R. K. Chailakhyan, V. I. Yusupov, A. P. Sviridov, Y. V. Gerasimov, A. Ch. Tambiev, N. N. Vorobieva, A. I. Kuralesova, I. L. Moskvina, V. N. Bagratashvili, "Acousic and EHF impact on bone marrow stromal stem cells in vitro," Biomed. Radioelectron. 2, 36-42 (2013).

36. A. J. Friedenstein, A. I. Kuralesova, "Osteogenic precursor cells of bone marrow in radiation chimeras," Transplantation 12, 99-108 (1971).

37. R. K. Chailakhyan, V. I. Yusupov, J. V. Gerasimov, P. A. Sobolev, A. H. Tambiev, N. N. Vorobieva, A. P. Sviridov, V. N. Bagratashvili, "Effect of hydrodynamic processes and low-intensity radiation with wavelengths $0,63 \mu \mathrm{m}$ and $7,1 \mathrm{~mm}$ on the proliferative activity of bone marrow stromal stem cells in vitro," Biomedicine 2, 24-29 (2011).

38. Yu. F. Gorskaya, O. V. Lebedinskaya, V. G. Nesterenko, R. Kh. Chailakhyan, Yu. V. Gerasimov, N. V. Latsinik, A. I. Kuralesova, E. N. Genkina, "Effect of $\alpha$-fetoprotein on the count of bone marrow and splenic stromal precursor cells and proliferation of their cultural descendants," Bull. Exp. Biol. Med. 143, 140-142 (2007).

39. R. K. Chaikhalyan, V. I. Yusupov, Yu. F. Corskaya, A. I. Kuralesova, Yu. V. Gerasimov, A. P. Sviridov, A. Kh. Tambiev, N. N. Vorobieva, A. G. Grosheva, V. V. Shishkova, I. L. Moskvina, V. N. Bagratashvili, "Effects of acoustic and EHF impulses on multipotent stromal cells during formation of bone marrow containing heterotopic organs in tissue engineered constructions," Bull. Exp. Biol. Med. 158, 688-691 (2015). 